\title{
BRPKM
}

Buletin Riset Psikologi dan Kesehatan Mental

http://e-journal.unair.ac.id/index.php/BRPKM

e-ISSN: 2776-1851

ARTIKEL PENELITIAN

\section{Pengaruh Workload dan Social Support terhadap Burnout pada Tenaga Kesehatan di Masa Pandemi COVID-19}

\author{
NOORIFTITA RIZKY \& FENDY SUHARIADI* \\ Fakultas Psikologi Universitas Airlangga
}

\begin{abstract}
ABSTRAK
Tujuan dari penelitian ini adalah mengetahui dan menganalisis ada atau tidaknya pengaruh beban kerja dan dukungan sosial terhadap kelelahan kerja pada tenaga kesehatan di masa pandemi COVID-19. Penelitian ini adalah penelitian kuantitatif dan melibatkan 110 tenaga kesehatan yang bekerja di rumah sakit yang menangani pasien COVID-19. Dalam mengukur variabel penelitian menggunakan instrumen MBI, RTLX, dan MSPSS. Analisis yang digunakan yaitu uji regresi linear berganda dengan bantuan IBM SPSS Statistics 26 for Windows. Hasil dari penelitian ini menunjukkan bahwa beban kerja dan dukungan sosial memiliki pengaruh yang signifikan terhadap kelelahan kerja pada tenaga kesehatan di masa pandemi COVID-19, baik secara simultan maupun parsial.
\end{abstract}

Kata kunci: beban kerja, covid-19, dukungan sosial, kelelahan kerja, tenaga kesehatan

\section{ABSTRACT}

The purpose of this research is to find out and analyze whether or not there is an effect of workload and social support on burnout in healthcare workers during the pandemic of COVID-19. The research used quantitative study and involving 110 healthcare workers who work in hospital that treat COVID-19 patients. In measuring the research variables using the MBI, RTLX, and MSPSS instruments. The analysis used is multiple linear regression test with IBM SPSS Statistics 26 for Windows. The results of this study indicate that workload and social support have a significant effect on burnout in healthcare workers during the pandemic of COVID-19, either simultaneously or partially.

Keywords: burnout, covid-19, healthcare workers, social support, workload

Buletin Penelitian Psikologi dan Kesehatan Mental (BRPKM), 2021, Vol. 1(2), 1199-1206

*Alamat korespondensi: Fakultas Psikologi Universitas Airlangga, Kampus B Universitas Airlangga Jalan Airlangga 4-6 Surabaya 60286. Surel: fendy.suhariadi@psikologi.unair.ac.id

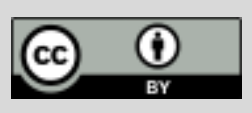

Naskah ini merupakan naskah dengan akses terbuka dibawah ketentuan the Creative Common Attribution License (CC-BY-4.0) (http://creativecommons.org/licenses/by/4.0), sehingga penggunaan, distribusi, reproduksi dalam media apapun atas artikel ini tidak dibatasi, selama sumber aslinya disitir dengan baik. 


\section{PE N D A H U L U A N}

Coronavirus Disease-19 (COVID-19) adalah penyakit yang disebabkan oleh virus corona baru atau SARSCoV-2 dan menyebabkan infeksi saluran pernapasan. Seiring berjalannya waktu, jumlah kasus COVID19 semakin meningkat dan terus menyebar luas. Akhirnya pada Maret 2020 World Health Organization (WHO) menetapkan COVID-19 sebagai pandemi. Pandemi ini menyebabkan ketidakpastian, perubahan yang drastis, dan keadaan yang di luar kendali menjadi tantangan baru bagi tenaga kesehatan dalam menangani pasien yang terinfeksi COVID-19. Berbagai ancaman mengintai tenaga kesehatan yang berada di garda terdepan di masa pandemi ini. Kekhawatiran muncul terkait pasokan alat pelindung diri (APD) yang kurang memadai, pemakaian APD yang menimbulkan rasa tidak nyaman, ancaman terinfeksi virus, intensitas bertemu dengan keluarga berkurang karena isolasi mandiri, munculnya stigma sebagai penyebar virus, hingga kematian (Giusti dkk., 2020; Sasangohar dkk., 2020).

Faktor risiko yang dialami tenaga kesehatan dalam menangani COVID-19 dapat memicu timbulnya burnout (Ornell dkk., 2020). Burnout menjadi prediktor penting dalam penurunan kinerja, produktivitas, dan kepuasan klien. Burnout juga membawa dampak negatif pada kesejahteraan psikologis dan kesehatan fisik (Bakker \& Sanz-Vergel, 2020). Tanda-tanda burnout yang tenaga kesehatan alami yaitu sedih dan depresi, mudah frustrasi, merasa terisolasi, kelelahan fisik dan mental, merasa gagal, dan rasa khawatir yang menyebabkan waspada berlebihan (Jha dkk., 2020). Di masa pandemi ini, tingkat burnout di kalangan tenaga kesehatan semakin meningkat (Lasalvia dkk., 2021). Adanya pandemi juga membawa faktor-faktor baru yang memengaruhi burnout pada tenaga kesehatan. Kegiatan belajar anak yang dilakukan secara online, pekerjaan rumah tangga yang menumpuk, tagihan rumah, dan menyaksikan pasien kesakitan, sekarat, hingga meninggal menimbulkan kelelahan secara emosional bagi tenaga kesehatan (Aldossari \& Chaudhry, 2021; Houtrow, 2020; Jha dkk., 2020). Secara global, titik puncak burnout tenaga kesehatan dapat terjadi ketika gelombang kedua atau ketiga pandemi, munculnya virus-virus jenis baru, dan meningkatnya angka kematian karena COVID-19 (Kaushik, 2021).

Secara garis besar dapat disimpulkan bahwa salah satu faktor yang memengaruhi burnout adalah workload. Workload bergantung pada jumlah pekerjaan yang harus dilakukan, waktu dan aspek tertentu yang perlu diperhatikan, dan pengalaman psikologis setiap individu (Lysaght dkk., 1989). Di masa pandemi COVID-19, waktu bekerja yang lebih lama, tekanan dari berbagai pihak, stres yang meningkat, dan kekhawatiran tertular virus menyebabkan workload tenaga kesehatan lebih besar dari biasanya (Rosyanti \& Hadi, 2020). Dalam beberapa penelitian sebelumnya telah disebutkan bahwa workload memengaruhi burnout secara signifikan (Hamzah, 2019; Indra, 2018; Prijayanti, 2015; Xiaoming dkk., 2014). Kelelahan emosional dan depersonalisasi yang dirasakan dapat menyebabkan hilangnya makna pekerjaan. Kemudian perasaan tidak percaya diri dengan kemampuan yang dimiliki juga memengaruhi dalam kualitas layanan yang diberikan.

Faktor lain yang memengaruhi burnout adalah social support (Hamzah, 2019; Indra, 2018; Woodhead dkk., 2014). Social support yang didapat tenaga kesehatan dapat memengaruhi kesehatan, meringankan masalah yang dihadapi, meningkatkan kepercayaan diri dan rasa optimis dalam pekerjaan, memiliki rasa aman dan nyaman, tingkat depresi yang rendah, kualitas tidur yang lebih baik, dan dapat mengatasi rasa terisolasi dari dunia luar (Iswanto \& Agustina, 2016; Liu dkk., 2020; Putri, 2016; Santoso \& Setiawan, 2018; Xiao dkk., 2020; Zhang \& Ma, 2020). Dukungan dari berbagai sumber dan bentuk sangat dibutuhkan oleh tenaga kesehatan di tengah pandemi COVID-19 ini. Dari organisasi, dukungan yang diberikan dapat berupa kebutuhan dasar, ketersediaan APD, fasilitas konseling dengan tenaga 
profesional, dan program regulasi jam kerja (Ho dkk., 2020; Kannampallil dkk., 2020). Kemudian dukungan dari keluarga dan teman terdekat dapat berupa kasih sayang dan semangat agar selalu memberikan yang terbaik dalam pekerjaan (Rosyanti \& Hadi, 2020).

\section{Burnout}

Burnout adalah sebuah sindrom psikologis berupa emotional exhaustion, depersonalization, dan low personal accomplishment yang dapat terjadi pada individu yang bekerja dengan banyak orang dalam kapasitas tertentu (Maslach dkk., 1996).

\section{Workload}

Workload adalah persepsi individu terhadap waktu yang digunakan untuk bekerja serta perbedaan antara tuntutan tugas yang diberikan dengan kemampuan yang dimiliki pekerja (Hart \& Staveland, 1988).

\section{Social Support}

Social support adalah keyakinan seseorang akan adanya dukungan yang diberikan oleh keluarga, teman, dan orang-orang terdekat pada saat dibutuhkan (Zimet dkk., 1988).

Berdasarkan pemaparan di atas, maka hipotesis dalam penelitian ini adalah sebagai berikut:

$\mathrm{H}_{1} \quad$ : Workload dan social support berpengaruh terhadap burnout (kelelahan kerja) pada nakes di masa pandemi COVID-19

$\mathrm{H}_{2} \quad$ : Workload berpengaruh terhadap burnout (kelelahan kerja) pada nakes di masa pandemi COVID-19

$\mathrm{H}_{3} \quad$ :Social support berpengaruh terhadap burnout (kelelahan kerja) pada nakes di masa pandemi COVID-19

\section{Desain Penelitian}

\section{E T O D E}

Dalam mendesain penelitian ini digunakan pendekatan kuantitatif yang memiliki data berupa angka, terdapat uji hipotesis, dan analisis data untuk menunjukkan hubungan antarvariabel (Neuman, 2014). Kemudian, tipe penelitian yang digunakan adalah eksplanatori yang memiliki tujuan untuk menjelaskan mengapa suatu fenomena terjadi serta untuk menguji teori yang sudah ada. Selanjutnya, teknik pengumpulan data yang digunakan adalah survei melalui kuesioner.

\section{Partisipan}

Partisipan dalam penelitian ini adalah tenaga kesehatan di rumah sakit yang menangani pasien COVID19. Pada penelitian ini teknik sampling yang digunakan adalah non-probability sampling dan convenience sampling. Penulis melakukan perhitungan menggunakan $G^{*}$ Power 3.1.9.7 dengan taraf signifikansi sebesar 0,05 dan statistical power sebesar 0,95 dalam rangka menentukan jumlah partisipan. Berdasarkan perhitungan tersebut, jumlah minimal sampel yang dibutuhkan adalah 107 partisipan. Setelah dilakukan pengambilan data, didapatkan total 110 partisipan $\left(M_{\text {usia }}=34,58 ; \mathrm{SD}_{\mathrm{usia}}=8,54 ; 61\right.$ 
persen wanita; 39 persen pria) yang setuju untuk berpartisipasi melalui informed consent dalam penelitian ini.

\section{Pengukuran}

Alat ukur yang digunakan untuk mengukur burnout adalah The Maslach Burnout Inventory (MBI) yang diadaptasi dari penelitian Karim berdasarkan teori Maslach (Karim, 2020). Terdiri dari 22 aitem dan 7 alternatif jawaban dari 0 sampai 6 dengan $\alpha=.715$. Kemudian, alat ukur workload adalah Raw-Task Load Index (RTLX) yang diadaptasi oleh Suryandari berdasarkan teori Hart dan Staveland (Suryandari, 2018). Terdiri dari 6 aitem dan 5 alternatif jawaban dari 1 sampai 5 dengan $\alpha=.745$. Selanjutnya, alat ukur yang digunakan untuk mengukur social support adalah The Multidimensional Scale of Perceived Social Support (MSPSS) yang diadaptasi dari penelitian Wibowo berdasarkan teori Zimet (Wibowo, 2019). Terdiri dari 12 aitem dan 5 alternatif jawaban dari 1 sampai 5 dengan $\alpha=.936$.

\section{Analisis Data}

Teknik analisisnya adalah uji asumsi dan uji regresi linear berganda. Uji asumsi yang dilakukan adalah uji normalitas, uji linearitas, uji heteroskedastisitas, dan uji multikolinearitas. Pengolahan data dalam penelitian ini menggunakan bantuan aplikasi IBM SPSS Statistics 26 for Windows.

\section{HAS I L P E N EL I T I A N}

Hasil analisis deskriptif menunjukkan bahwa partisipan memiliki tingkat workload kategori tinggi sebanyak 77 partisipan (70\%), kategori sedang sebanyak 30 partisipan $(27,2 \%)$, dan kategori rendah sebanyak 3 orang $(2,8 \%)$. Untuk social support partisipan dengan kategori tinggi sebanyak 100 partisipan (91\%) dan kategori sedang sebanyak 10 partisipan (9\%). Selanjutnya untuk tingkat burnout kategori sedang sebanyak 34 partisipan (31\%) dan kategori rendah sebanyak 76 partisipan (69\%).

Hasil uji regresi linear berganda menunjukkan bahwa workload dan social support dapat memprediksi burnout pada tenaga kesehatan sebesar $12,9 \%\left(\mathrm{~F}=7,921 ; \mathrm{p}=0,001 ; \mathrm{R}^{2}=0,129\right)$. Kemudian dari hasil uji parsial diketahui bahwa workload memiliki pengaruh terhadap burnout pada tenaga kesehatan ( $\mathrm{p}=0,009$ dan $\mathrm{R}^{2}=0,036$ ) dan social support juga berpengaruh terhadap burnout pada tenaga kesehatan $\left(\mathrm{p}=0,001\right.$ dan $\left.\mathrm{R}^{2}=0,071\right)$.

\section{I S K U S I}

Penelitian ini bertujuan untuk mengetahui dan menganalisis ada atau tidaknya pengaruh workload dan social support terhadap burnout (kelelahan kerja) pada nakes di masa pandemi COVID-19. Berdasarkan analisis data yang telah dilakukan menunjukkan bahwa workload dan social support memiliki pengaruh yang signifikan $(\mathrm{p}=0,001)$ terhadap burnout. Kemudian ditinjau dari nilai koefisien determinasi menunjukkan nilai sebesar 0,129 yang artinya bahwa workload dan social support secara bersamaan memberikan pengaruh sebesar $12,9 \%$ terhadap burnout. Hasil penelitian ini sejalan dengan penelitian yang menemukan bahwa burnout dapat dipengaruhi oleh workload dan social support secara bersamaan (Prijayanti, 2015). Penelitian lain juga menunjukkan kontribusi workload dan social support yang cukup besar yaitu 40,3\% terhadap kemungkinan terjadinya burnout (Hamzah, 2019).

Selanjutnya diketahui bahwa workload memiliki pengaruh positif dan signifikan $(\mathrm{p}=0,009)$ terhadap burnout. Artinya semakin tinggi workload yang diterima oleh tenaga kesehatan, maka semakin tinggi

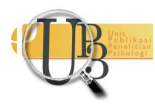


pula tingkat burnout yang dialami. Hasil pada penelitian ini sesuai dengan penelitian yang telah dilakukan sebelumnya yang menjelaskan yaitu kecenderungan burnout timbul ketika workload semakin buruk (Xiaoming dkk., 2014). Kemudian dalam penelitian lain juga mengemukakan tenaga kesehatan yang memaksakan diri dalam menyelesaikan pekerjaannya akan merasakan kelelahan yang luar biasa, sehingga hal tersebut memengaruhi kinerja tenaga kesehatan dalam memberikan layanan pada pasien (Indra, 2018). Hal ini kembali dipertegas dalam penelitian serupa yang mengatakan kelelahan akibat workload yang berlebih dapat menyebabkan berkurangnya kekuatan fisik untuk melanjutkan pekerjaan tersebut dan dapat menurunkan motivasi serta produktivitas kerja (Hamzah, 2019).

Kemudian diketahui bahwa social support berpengaruh signifikan dan memiliki arah negatif $(\mathrm{p}=0,001)$ terhadap burnout. Artinya semakin tinggi tingkat social support yang diterima oleh tenaga kesehatan, maka semakin rendah tingkat burnout yang dialami. Hasil ini sesuai dengan penelitian yang telah dilakukan sebelumnya yang menunjukkan bahwa social support berpengaruh secara negatif dan signifikan terhadap burnout (Indra, 2018). Hal ini didukung oleh Hamzah yang menyebutkan bahwa lingkungan kerja yang baik maka akan menghasilnya social support yang baik pula sehingga akan mengurangi intensitas burnout yang dialami (Hamzah, 2019). Putra dan Muttaqin juga mengungkapkan bahwa kualitas atau kepuasan dalam menerima social support lebih penting untuk menekan terjadinya burnout (Putra \& Muttaqin, 2020).

\section{S I M P U L A N}

Berdasarkan hasil analisis dan pembahasan dalam penelitian ini, maka dapat disimpulkan bahwa workload dan social support secara simultan memiliki pengaruh yang signifikan terhadap burnout (kelelahan kerja) pada nakes di masa pandemi COVID-19. Kemudian ditemukan bahwa workload secara parsial berpengaruh signifikan dan positif terhadap burnout (kelelahan kerja) pada nakes di masa pandemi COVID. Selanjutnya social support secara parsial berpengaruh secara signifikan dan negatif terhadap burnout (kelelahan kerja) pada nakes di masa pandemi COVID-19.

Saran untuk penelitian selanjutnya dapat lebih mempertimbangkan karakteristik subjek berdasarkan data demografis seperti status pernikahan dan profesi tenaga kesehatan yang lebih spesifik untuk mendapatkan hasil yang lebih detail dan jelas. Selain itu dapat meneliti faktor lain yang dapat memprediksi tingkat burnout seperti self efficacy yang berkaitan dengan low personal accomplishment. Saran bagi tenaga kesehatan untuk melakukan penerimaan diri bahwa tugas yang dihadapi merupakan bagian dari tanggung jawab sebagai penyedia fasilitas kesehatan dan tidak perlu sungkan untuk meminta bantuan sesuai dengan yang dibutuhkan. Kemudian saran bagi rumah sakit untuk dapat memerhatikan jadwal kerja dan mengadakan program social support seperti fasilitas konsultasi gratis dengan tenaga profesional.

\section{U C AP A N T ERIMAKASIH}

Terima kasih kepada Allah SWT, keluarga, teman-teman, partisipan penelitian, dan seluruh pihak yang telah memberikan dukungan dan bantuan selama proses penelitian. Semoga selalu diberkahi kesehatan dan kebahagiaan. 


\section{DEKLARASI POTENSI TERJADINYAKONFLIK KEPENTINGAN}

Nooriftita Rizky dan Fendy Suhariadi tidak bekerja, menjadi konsultan, memiliki saham, atau menerima dana dari perusahaan atau organisasi manapun yang mungkin akan mengambil untung dari diterbitkannya naskah ini.

\section{PUS T AKA ACUAN}

Aldossari, M., \& Chaudhry, S. (2021). Women and Burnout in the Context of a Pandemic. Gender, Work and Organization, 28(2), 826-834. https://doi.org/10.1111/gwao.12567

Bakker, A. B., \& Sanz-Vergel, A. I. (2020). Burnout. In B. J. Carducci \& C. S. Nave (Eds.), The Wiley Encyclopedia of Personality and Individual Differences: Clinical, Applied, and Cross-Cultural Research: Vol. IV (1st ed., pp. 411-415). John Wiley \& Sons Ltd.

Giusti, E. M., Pedroli, E., D’Aniello, G. E., Stramba Badiale, C., Pietrabissa, G., Manna, C., Stramba Badiale, M., Riva, G., Castelnuovo, G., \& Molinari, E. (2020). The Psychological Impact of the COVID-19 Outbreak on Health Professionals: A Cross-Sectional Study. Frontiers in Psychology, 11, 1-27. https://doi.org/10.3389/fpsyg.2020.01684

Hamzah, W. (2019). Pengaruh Beban Kerja dan Dukungan Sosial terhadap Kelelahan Kerja. Psikoborneo, $7(2), 336-343$.

Hart, S. G., \& Staveland, L. E. (1988). Development of NASA-TLX (Task Load Index): Results of Empirical and Theoretical Research. Human Mental Workload., 52, 139-183.

Ho, C. S., Chee, C. Y., \& Ho, R. C. (2020). Mental Health Strategies to Combat the Psychological Impact of COVID-19 Beyond Paranoia and Panic. Annals of the Academy of Medicine, Singapore, 49(3), 155160.

Houtrow, A. J. (2020). Addressing Burnout: Symptom Management Versus Treating the Cause. The Journal of Pediatrics, 224, 18-19. https://online210.psych.wisc.edu/wp-content/uploads/PSY210_Unit_Materials/PSY-

210_Unit01_Materials/Frost_Blog_2020.pdf\%0Ahttps://www.economist.com/specialreport/2020/02/06/china-is-making-substantial-investment-in-ports-and-pipelinesworldwide\%0Ahttp://

Indra, I. P. (2018). Pengaruh Beban Kerja dan Dukungan Sosial terhadap Burnout pada Perawat RSUD Dr. Achmad Darwis Kecamatan Suliki Kabupaten Lima Puluh Kota. Universitas Negeri Padang.

Iswanto, F., \& Agustina, I. (2016). Peran Dukungan Sosial di Tempat Kerja Terhadap Keterikatan Kerja Karyawan. Mediapsi, 02(02), 38-45. https://doi.org/10.21776/ub.mps.2016.002.02.6

Jha, S. S., Shah, S., Calderon, M. D., Soin, A., \& Manchikanti, L. (2020). The Effect of COVID-19 on Interventional Pain Management Practices: A Physician Burnout Survey. Pain Physician, 23(4 Special Issue), S271-S282.

Kannampallil, T. G., Goss, C. W., Evanoff, B. A., Strickland, J. R., McAlister, R. P., \& Duncan, J. (2020). Exposure to COVID-19 Patients Increases Physician Trainee Stress and Burnout. PLoS ONE, 15(8),

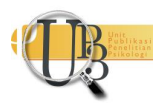


1-12. https://doi.org/10.1371/journal.pone.0237301

Karim, A. (2020). Pengaruh Kecerdasan Emosional terhadap Burnout pada Perawat di Surabaya dengan Coronavirus Anxiety sebagai Variabel Mediator [Universitas Airlangga]. http://mpoc.org.my/malaysian-palm-oil-industry/

Kaushik, D. (2021). COVID-19 and Health care Workers Burnout: A Call for Global Action. EClinicalMedicine, 35, 1. https://doi.org/10.1016/j.eclinm.2021.100808

Lasalvia, A., Amaddeo, F., Porru, S., Carta, A., Tardivo, S., Bovo, C., Ruggeri, M., \& Bonetto, C. (2021). Levels of Burn-out among Healthcare Workers during the COVID-19 Pandemic and Their Associated Factors: A Cross-sectional Study in a Tertiary Hospital of a Highly Burdened Area of North-east Italy. BMJ Open, 11, 1-20. https://doi.org/10.1136/bmjopen-2020-045127

Liu, C. H., Zhang, E., Wong, G. T. F., Hyun, S., \& Hahm, H. “Chris.” (2020). Factors Associated with Depression, Anxiety, and PTSD Symptomatology during the COVID-19 Pandemic: Clinical Implications for U.S. Young Adult Mental Health. Psychiatry Reserach 290, 1-7.

Lysaght, R. J., Hill, S. G., Dick, a O., Plamondon, B. D., Linton, P. M., Wierwille, W. W., Zaklad, a L., Bittner Jr, a C., \& Wherry, R. J. (1989). Operator Workload: Comprehensive Review and Evaluation of Operator Workload Methodologies. In U.S. Army Research Institute for the Bohavioral and Social Sciences (Vol. 851).

Maslach, C., Jackson, S. E., \& Leiter, M. P. (1996). The Maslach Burnout Inventory Manual. The Maslach Burnout Inventory, May 2016, 191-217. https://www.researchgate.net/publication/277816643

Neuman, W. L. (2014). Social Research Methods: Qualitative and Quantitative Approaches. In Pearson Education Limited (7th ed.). Pearson Education Limited. https://doi.org/10.2307/3211488

Ornell, F., Schuch, J. B., Sordi, A. O., \& Kessler, F. H. P. (2020). “'Pandemic Fear"' and COVID-19: Mental Health Burden and Strategies. Brazilian Journal of Psychiatry, 42(3), 232-235. https://doi.org/10.1590/1516-4446-2020-0008

Prijayanti, I. (2015). Pengaruh Beban Kerja dan Dukungan Sosial terhadap Burnout pada Karyawan PT. $X$. Universitas Islam Negeri Syarif Hidayatullah.

Putra, A. C. M., \& Muttaqin, D. (2020). Hubungan antara Dukungan Sosial dengan Burnout pada Perawat di Rumah Sakit X. Psikostudia: Jurnal Psikologi, 9(2), 82-87. https://doi.org/10.30872/psikostudia.v9i2.3901

Putri, D. R. (2016). Peran Dukungan Sosial dan Kecerdasan Emosi terhadap Kesejahteraan Subjektif pada Remaja Awal. Jurnal Indigenous, 1(1), 1-12. https://doi.org/10.23917/indigenous.v1i1.1770

Rosyanti, L., \& Hadi, I. (2020). Dampak Psikologis dalam Memberikan Perawatan dan Layanan Kesehatan Pasien COVID-19 pada Tenaga Profesional Kesehatan. Health Information Jurnal Penelitian, 12(1), 107-130. https://doi.org/10.36990/hijp.vi.191

Santoso, E., \& Setiawan, J. L. (2018). Peran Dukungan Sosial Keluarga, Atasan, dan Rekan Kerja terhadap Resilient Self-Efficacy Guru Sekolah Luar Biasa. Jurnal Psikologi, 45(1), 27-39. https://doi.org/10.22146/jpsi.25011

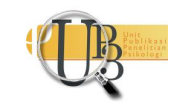


Sasangohar, F., Jones, S. L., Masud, F. N., Vahidy, F. S., \& Kash, B. A. (2020). Provider Burnout and Fatigue during the COVID-19 Pandemic: Lessons Learned from a High-Volume Intensive Care Unit. International Anesthesia Research Society, 131(1), 106-111. https://doi.org/10.1213/ANE.0000000000004866

Suryandari, D. (2018). Pengaruh Kompetensi, Motivasi, dan Beban Kerja terhadap Kinerja Perawat IGD RSUD di Yogyakarta. Universitas Muhammadiyah Yogyakarta.

Wibowo, B. H. (2019). Pengaruh Dukungan Sosial terhadap Kecemasan Menghadapi Pensiun pada Pegawai Kementerian Pertahanan [Universitas Negeri Jakarta]. http://psikologi.unj.ac.id/

Woodhead, E. L., Northrop, L., \& Edelstein, B. (2014). Stress, Social Support, and Burnout Among LongTerm Care Nursing Staff. Journal of Applied Gerontology, 1-22. https://doi.org/10.1177/0733464814542465

Xiao, H., Zhang, Y., Kong, D., Li, S., \& Yang, N. (2020). The Effects of Social Support on Sleep Quality of Medical Staff Treating Patients with Coronavirus Disease 2019 (COVID-19) in January and February 2020 in China. Medical Science Monitor, 26, 1-8. https://doi.org/10.12659/MSM.923549

Xiaoming, Y., Ma, B. J., Chang, C. L., \& Shieh, C. J. (2014). Effects of Workload on Burnout and Turnover Intention of Medical Staff: A Study. Studies on Ethno-Medicine, 8(3), 229-237. https://doi.org/10.31901/24566772.2014/08.03.04

Zhang, Y., \& Ma, Z. F. (2020). Impact of the COVID-19 Pandemic on Mental Health and Quality of Life among Local Residents in Liaoning Province, China: A Cross-Sectional Study. [revista en Internet] 2020 [acceso 8 de octu. International Journal of Environmental Research and Public Health, 17, 112. https://pubmed.ncbi.nlm.nih.gov/32233719/

Zimet, G. D., Dahlem, N. W., Zimet, S. G., \& Farley, G. K. (1988). The Multidimensional Scale of Perceived Social Support. Journal of Personality Assessment, 52(1), 30-41. https://doi.org/10.1207/s15327752jpa5201_2 